\title{
ESPAÇO PLURAL
}

\section{GUITA LVOVNA VIGODSKAIA ( $925-20$ I0), FILHA DE VIGOTSKI: ENTREVISTA}

\section{ZOIA PRESTES}

Professora do Curso de Psicologia do Centro Universitário de Brasília

81629891z@gmail.com

Em 13 de julho último, após receber a notícia do falecimento de Guita, vieram-me à mente aqueles momentos que vivenciamos na sua casa acolhedora, em que nos recebeu para uma entrevista. Nosso grupo, composto por Elizabeth Tunes, Elizângela Peraci, Patrícia Pederiva, Tereza Mudado e eu, estava muito ansioso. Guita era psicóloga e dedicava-se aos estudos da defectologia. Apesar de desenvolver estudos valiosos sobre a brincadeira infantil e o desenvolvimento atípico, conforme comentário do professor Kudriavtsev, nunca defendeu uma tese de doutorado, dedicando-se de corpo e alma à herança acadêmica do pai. Graças a ela e a alguns colaboradores de Vigotski, como Luria e Leontiev, o mundo teve acesso às obras do teórico. Mesmo antes de escrever a biografia do pai em parceria com Tâmara Mikhailovna Lifanova, Guita abriu os arquivos de fotos e documentos para vários estudiosos estrangeiros da obra do psicólogo.

A biografia que escreveu saiu apenas em 1996 e é um registro detalhado de toda a trajetória de Vigotski vista pelo olhar dos amigos, colaboradores e inimigos e, também, pelos olhos da filha, que narra histórias emocionantes vividas com o pai.

Em 9 de maio de 2010, Guita completou 85 anos de vida. Mas o calor intenso e incomum do verão moscovita agravou sua saúde já bastante debilitada. A triste notícia de sua morte chegou via e-mail. Escrevia-me uma das maiores estudiosas das obras de Vigotski na Rússia de hoje, Ekaterina Zaverchneva, que realiza um trabalho de resgate dos originais do pensador.

A entrevista que se segue apresenta dados interessantes para todos que se interessam pela teoria histórico-cultural e, ao publicá-la, queremos fazer uma homenagem àquela que foi a guardiã da obra de Levi Semionovith Vigotski. 


\section{ENTREVISTA COM GUITA LVOVNA VIGODSKAIA}

\section{Moscou, 9 de novembro de 2007}

- Você não está em Moscou pela primeira vez? - perguntou-me Guita Lvovna.

- Não - respondi - morei aqui I 5 anos.

- Fala muito bem o russo, aliás, parece russa - disse-me Guita um pouco desconfiada.

- Não, sou brasileira, mas me sinto muito russa, passei aqui parte da infância e juventude.

- Mas suas colegas não falam, não é mesmo? Isso é maravilhoso, você acompanhar as pessoas que não falam uma palavra da nossa língua e trazê-las para conhecer o país. Sabe, numa certa época, há muito tempo... Não faz mal que já comecei a contar? - perguntou Guita, iniciando a entrevista.

- Não, ao contrário, estamos muito felizes e curiosas, esperamos muito por este dia.

Guita: Houve um Simpósio, em um país da Escandinávia. Lá, estava uma pessoa, vocês devem conhecer pelas leituras, Davidov [Vassilii Vassilievitch]. Aproximou-se dele um cientista holandês, Rene Vander-Veer, eu conheço bem esse nome, pois ficamos muito amigos. Ele se aproximou de Davidov com algumas perguntas. Este me disse que respondeu às perguntas de Rene, mas depois acrescentou: "O senhor não vai entender nada, tem de ler Vigotski no original". Rene respondeu: "Daqui a um ano vou ler Vigotski no original russo". Um ano ou um ano e meio depois, telefonou-me Davidov dizendo: "Você imagina, está em Moscou Rene Vander-Veer! Está falando russo e quer muito encontrá-la". Eu não tinha como recebê-lo em minha casa e fiquei pensando: "O que fazer?" Aí, Davidov me disse: "Ele vem à minha casa, venha também, faremos o encontro aqui". Peguei umas fotos e alguns documentos, pois ainda não tinha meu livro, e fui. Assim, conheci Rene Vander-Veer! e ficamos amigos. Há muito tempo que não o vejo e a última vez que nos encontramos foi na Dinamarca. Ele já escreveu vários livros sobre Vigotski (três, eu acho). 
Zoia: Nós preparamos algumas perguntas e gostaríamos que respondesse, por favor.

Guita: Vou tentar.

Zoia: Obrigada. Algumas fontes estrangeiras dizem que não existiu a troika Luria, Vigotski e Leontiev. A senhora acha que ela não existiu?

Guita: Como não houve... Posso mostrar sobre isso em Luria e até mesmo Leontiev não negava isso, só mais no final. Existiu a troika, eles se encontravam na nossa casa. Naquela época, vivíamos num quarto - Lev Semionovitch não tinha uma casa grande, eu agora vivo assim, numa casa ampla, mas naquela época era um quarto só, e a família, composta por quatro pessoas, vivi lá. Os encontros aconteciam lá, e tudo acontecia diante dos meus olhos. Eu adormecia ouvindo as conversas deles, deitava às oito e meia da noite, fechava os olhos e tudo me parecia chato e pouco interessante. Mas depois, a troika se transformou em vosmiorka [octeto].

Zoia: Quem eram os componentes da vosmiorka?

Guita: Naquela época, ainda eram estudantes: Zaporojets, Morozova, Levina Rosa levguenievna, Bojovitch Lidia Ilinichna, Slavina Leia Salomonovna e Leontiev, Luria e Vigotski. E quando juntos começaram a pensar e desenvolver, a partir de 1927, a teoria histórico-cultural, então cada um desses membros, até mesmo os estudantes, recebeu a sua tarefa concreta. Ocupavam-se de pictogramas, cada um desenvolvia seu eixo e, nas reuniões da vosmiorka, cada um apresentava o seu relatório, discutia-se o que cada um conseguiu obter e se planejavam os próximos passos. A troika existiu sim, eu garanto.

Zoia: Quanto tempo os três trabalharam juntos até a partida de Leontiev para Rharkov?

Guita: Leontiev foi, mas voltou. Lev Semionovitch ia a Rharkov constantemente. ○ trabalho, num certo sentido, não foi interrompido. Depois, o "quinteto" se separou. Bojovitch ficou em Rharkov por um curto tempo, depois foi para Poltava e trabalhou lá por muitos anos. Alguém foi para Kursk. Natalia Grigorievna Morozova me contou que trabalhou em algum lugar na região de Nijni Novgorod e, posteriormente, na Sibéria. Quando estavam nessas cidades, eles acumulavam dias de folga e, então, viajavam para Moscou, onde passavam alguns dias e lá, relatavam o que tinham feito, recebiam outras tarefas e as 
discutiam juntos. De fato, trabalharam praticamente até a morte de Vigotski, que ocorreu em 1934. A troika existiu praticamente desde 1924 até 1934. E os dois [Leontiev e Luria] estiveram no enterro de Vigotski.

Zoia: A senhora escreveu seu livro antes de encontrarem a carta que Leontiev dirigiu a Vigotski. A senhora leu a biografia de Leontiev?

Guita: Eu não posso comentar a carta de Leontiev, mas o que escrevi é verdade. Ele [Leontiev] parou de frequentar a nossa casa em 1933. Pois, lembro-me que, em 1947, nós passávamos muita necessidade com a minha mãe, e tinha sido organizada a Academia de Ciências Pedagógicas. Aleksandr Romanovitch Luria, que era mais próximo de nós e preocupado com a nossa sobrevivência, havia resolvido que a Academia deveria comprar o arquivo de Vigotski. Nesse caso, o arquivo deveria ficar num lugar decente, e nós receberíamos algum dinheiro para que a minha mãe pudesse nos manter, a minha irmã e eu. Mas, para comprar o arquivo eram necessárias opiniões de dois acadêmicos. Um era Luria e ele já tinha dado o seu parecer. E o segundo foi Leontiev, que Luria levou à nossa casa. Eu me lembro muito bem, ele veio e, diante da entrada na sala, parou constrangido. Minha mãe virou-se para ele e perguntou: "Aleksei Nikolaievitch, o senhor se lembra há quantos anos deixou de vir aqui?" Ele não respondeu nada, era uma pessoa difícil... Meu professor Zaporojets, que gostava muito dele, compreendeu isso e comentou comigo: "Liocha não é mais o mesmo".

Zoia: Ele era uma pessoa difícil em que sentido?

Guita: Em suas próprias avaliações, na superavaliação dos fatos. Por isso, não quero comentar a carta. Mas, é verdade tudo o que escrevi, não escrevi nada que não tenha sido confirmado. Eu conversei sobre isso com a minha mãe, perguntei a ela: "Mãe, o que aconteceu?" E ela me contou que aconteceu essa história, que ele escreveu uma carta para Luria, dizendo que Vigotski era o "ontem". Então, Luria, sem pensar, respondeu sim para ele e, depois, pensou melhor, correu até Vigotski (que estava doente naquela época) e contou tudo a ele. É claro que isso não elevou o ânimo de Vigotski, mas tinham sido colocados os pingos nos "is". Além disso, no enterro de Lev Semionovitch, Luria ficou perto de mim e eu estava junto com Chif (que tomava conta de mim), aluna de Lev Semionovitch, e, de repente, Luria passou rapidamente por nós, foi até o caixão e ficou de guarda. Não ficou muito tempo e me parece que foi 
Zankov (não me lembro muito bem) que tirou Luria da guarda. Agora, quanto a Leontiev, nem deixaram chegar perto. Todos os alunos moscovitas sabiam disso. $\bigcirc$ que ele escreve na carta que foi encontrada, que Deus o julgue. Mas isso existiu, e o grupo moscovita de defestólogos, que trabalhava com Lev Semionovitch, não perdoou Leontiev até o fim. Então, julguem vocês, se existiu ou não.

Zoia: Desculpe, mas tivemos acesso à carta e ficamos curiosas.

Guita: É claro, Zoia, isso é a vida, são fatos...

Zoia: $\bigcirc$ meu trabalho é todo sobre Vigotski, por isso tudo me interessa.

Guita: Sim, eu entendo. Quando li a carta vi que era mentira, escrevi nas margens "mentira" e fiquei chateada, não quis mais ler e deixei de lado. Dima [Dmitri Aleksandrovitch] não me é simpático, que viva como quiser.

Zoia: Algumas fontes informam que Vigotski foi deputado da Região Frunze de Moscou.

Guita: É verdade. Ele se ocupava das escolas. No livro está tudo. Está a característica dele. Ele não era membro do partido e isso, imagine, naquela época... um cientista fora do partido... Lá está que ele supervisionava escolas da região, as escolas auxiliares, as instituições metodológicas, visitava as crianças em situações difíceis que ficavam em casa e dava recomendações... Foram dois mandatos, mas ele morreu antes de terminar o segundo.

Zoia: Os deputados eram indicados ou eleitos?

Guita: As eleições não eram como são agora, não sei como era. Mas era um dos poucos cientistas que não era membro do partido.

Zoia: Ele conhecia a Krupskaia?

Guita: Sim, é verdade. Ela trabalhava no Narcompros e Lev Semionovitch dirigia a comissão de Spon. Por isso, Krupskaia falava com ele somente a respeito do trabalho. Até mesmo a irmã de Lev Semionovitch, minha tia, contou que ele se gabava diante dela: "Sabe com quem eu estive hoje?" Eram relações de trabalho, não tinham nenhuma relação pessoal. Ele era subordinado a ela.

Zoia: Ele era uma pessoa religiosa? 
Guita: Não posso responder a essa pergunta com precisão. Conhecia muito bem a Bíblia, conhecia bem a história da religião. Sei que ele respeitava muito aqueles que acreditavam e sempre liberava a nossa babá para ir à igreja e ela, às vezes, me levava. Certo dia, revelei isso a meu pai, ele não brigou, pelo contrário, só perguntou se tinha sido interessante para mim e se eu não incomodava a babá. Quando ele teve que explicar a oração que a babá me ensinou, explicou rapidamente. E quando eu perguntei: existe Deus ou não? Ele disse: "Cada pessoa resolve essa questão por si mesma". Sua babá acredita que existe Deus, outros não acreditam. Mas, ele falava sobre esse assunto com as irmãs, eram relações muito fortes, era uma família muito unida. Comversei com três de suas cinco irmãs e com a avó, que viveu um ano a mais que os filhos. Conversei sobre isso com as minhas tias e com a minha mãe. Todas me disseram que não podiam ser categóricas, mas, tudo indica que ele não tinha religião.

Zoia: Eram judeus e festejavam as datas judaicas?

Guita: Não, só a Páscoa. Nada mais. Até, quando menina eu disse a minha avó: "Você não segue as tradições!". Ela me disse: "A Páscoa é uma tradição que é para mim muito querida porque me traz lembranças da infância e da juventude". Então, quando era Páscoa, tirava-se a louça pascoal, lavava-se e durante uma semana ela e meu avô faziam matsuri. Era a única tradição, e o vovô antes da Páscoa ia à Sinagoga. Depois, vinha a Páscoa ortodoxa e a festejavam por causa da babá.

Zoia: Hoje, vocês comemoram a Páscoa judaica?

Guita: Não, só a da religião ortodoxa. $\bigcirc$ marido da Lena [a filha de Guita] é ortodoxo e Lena é metade ortodoxa, eu também. Crescemos nessa cultura russa. Não conheço a cultura judaica, não tenho interesse.

Zoia: Em seu livro a senhora escreve que um dos primeiros livros que Lev Semionovith ganhou do pai foi Ética, de Espinosa. Por que esse livro?

Guita: Lev Semionovitch estudava bem em todas as áreas e principalmente na literatura. $\bigcirc$ vovô era uma pessoa muito difícil, mas sensível. Permaneceu um manuscrito de meu pai inacabado, Estudo das emoções. Há muitos manuscritos. Eu penso que os médicos não entendiam o quanto a doença já tinha avançado, mas ele sabia. E eu confirmei isso, depois, em uma das cartas de minha mãe. 
Ele foi internado no dia 2 de junho e, de 10 para II, morreu; acho que a avaliação dos médicos não era das melhores.

Zoia: Lemos também que Lev Semionovitch ingressou na universidade pelo sistema de cotas para judeus?

Guita: Sim, foi por cota e, depois, por sorteio. Para que não entrassem só os mais talentosos, mas outras pessoas também. Nesse caso, os documentos foram enviados e os parentes depois mandaram avisar que ele havia sido aceito.

Zoia: E a revista Veresk?

Guita: Certa vez, quando já estava escrevendo a biografia do meu pai, começamos a procurar nas bibliotecas do país se havia algum exemplar da revista. Conheci um rapaz que estava fazendo um trabalho sobre Vigotski e conversei muito com ele. Ficou, por isso, muito grato a mim. Certo dia, me ligou, dizendo que tinha lido, em artigo de um estudioso, que havia encontrado certa informação na revista Veresk, na Biblioteca de Leningrado. Então, eu e Tamara Lifanova fomos até a biblioteca e pedimos para ver a revista. Fotografamos, copiamos... No livro tem a cópia de uma das capas. Posteriormente, já no trabalho de preparação da edição das obras completas, encontramos entre os manuscritos, que estão nos arquivos da família, um exemplar da revista Veresk.

Zoia: E por que Veresk?

Guita: Está na epígrafe da revista: é uma flor que não tem valor nenhum por ela mesma, mas prepara a terra para tudo o que for plantado. Vigotski, como redator, dizia que gostaria que a revista preparasse o leitor para conhecer as valiosas obras da literatura. $\bigcirc$ endereço da revista era a casa de Vgotski e acho difícil que tenha havido algum número sobre a literatura brasileira, ou que a tenha incluído.

Zoia: Exitem trabalhos de Vigotski sobre música?

Guita: Ele gostava de música, de ouvir, mas era uma arte que ele não dominava muito.

Zoia: Qual era a relação de Vigotski com Lunatcharski?

Guita: Não era uma relação pessoal, somente profissional. 
Zoia: Ele fez uma resenha sobre uma obra de Lunatcharski.

Guita: Sim, ele escreveu ainda no período de Gomel. Ele escreveu muitas resenhas e tudo era publicado na Poniedelnik e Komertcheskaia Gazeta. Mas, nunca mais foi publicado de novo.

Zoia: E a escola para crianças cegas, surdas e mudas em Zagorsk?

Guita: Já não é, infelizmente, mais como antes. Ivan Afanasievitch Sokolianski foi quem fundou a instrução para crianças cegas, mudas e surdas na Rússia. Durante um período, ele foi até comissário da educação da Ucrânia, criou a primeira instituição no mundo para as crianças cegas, surdas e mudas em Rharkov. E a escola foi maravilhosamente equipada. Por algum motivo, Vorochilov desenvolveu uma relação muito positiva com essa instituição e, por isso, Ihe destinava muitas verbas. Os equipamentos eram comprados na Alemanha. E quando chegou a guerra, quando os alemães invadiram Rharkov, aquelas crianças que não houve tempo de levar embora, ou de os parentes chegarem, foram mortas pelos fascistas, a instituição foi depredada e todo o equipamento roubado. Olga Skororrodova, uma das primeira alunas de Ivan Afanasievitch, ficou dois anos vivendo escondida no porão da casa de uma mulher maravilhosa que cuidou dela.

Depois disso, o pupilo de Sokolianski, um grande amigo, Aleksandr Ivanovitch Mecheriakov, dedicou-se à reabertura dessa instituição para as crianças. Sokolianski não viveu para ver, mas Aleksandr a visitou e ajudava na organização dos trabalhos. Mas este morreu em 1974, muito jovem, com 5 I anos. Eu mantinha relações amistosas com a família. Esta havia gasto muitas energias para reabrir essa instituição e, quando Aleksandr morreu, se começou a discutir quem a iria administrar. Resultado: venceu uma pessoa que não é das melhores e, por isso... Eu tinha amizade com os cegos, surdos e mudos mais velhos. Agora...

Zoia: A senhora viu o filme?

Guita: Natacha Krilatova, conheço bem, ela tem duas filhas e é casada com um homem normal. Por um tempo ela esteve no laboratório de Guenadii. Ela é uma pessoa muito capaz, muito inteligente. Não matriculou as filhas em escolas, ela mesma ocupou-se da educação e da instrução das filhas. Ou seja, uma mãe 
cega, surda e muda ensinou as duas filhas que enxergam, falam e ouvem. E são duas meninas maravilhosas. Ela mesma fala bem, só a voz é que é diferente.

Zoia: Havia um convênio de colaboração entre a escola de Zagorsk e o Instituto de Psicologia da Universidade de Moscou?

Guita: Eram quatro pessoas que estavam desde o início da organização. Mas, houve uma traição. Uma casou-se com certa mulher que queria só fazer carreira. Eu a conheci bem, encontrei-a algumas vezes em eventos. Depois de um tempo, cada um foi para o seu lado.

Zoia: Além de Psicologia da arte existem outros trabalhos de Vigotski sobre a arte?

Guita: Há vários trabalhos. No volume 6 das Obras reunidas há também a Psicologia do ator e algumas anotações de quando Vigotski era jovem. Há trabalhos do tipo "como lecionar literatura na escola". Mas estudos assim como o da Psicologia da arte, não.

Zoia: A senhora sabe que a edição americana de Michlenie i retch é resumida. que pensa sobre isso?

Guita: Naquela época, nós ficávamos contentes que tivesse saído daquele jeito. Ainda mais porque o prefácio foi escrito por Brunner. Além disso, tudo foi feito por Luria e dizer a ele que estávamos infatisfeitos com alguma coisa não tinha como. De fato esse livro foi o impulso para que o mundo ocidental conhecesse Vigotski, ninguém o conhecia. Logo depois recebemos uma avalanche de cartas. Em 1966, houve um Congresso de Psicologia...

Lena, a filha de Guita, nos entrega alguns livros e Guita se despede.

Recebido em: julho de 2010

Aprovado para publicação em: setembro de 2010 